\title{
PENGEMBANGAN MEDIA PEMBELAJARAN ASAM BASA INOVATIF BERBASIS GREEN LABYRINTH UNTUK SMA
}

\author{
Johnsen Harta ${ }^{1}$, Stella Afrilita Limbong ${ }^{1}$, Ester Elinawati Waruwu ${ }^{1}$
}

1. Prodi Pendidikan Kimia, Universitas Sanata Dharma, Paingan, Maguwoharjo, Depok, Sleman, Yogyakarta, Indonesia

\begin{abstract}
Abstrak - Media pembelajaran merupakan salah satu bagian yang esensial dalam menunjang keberhasilan proses belajar mengajar. Kebermaknaan suatu pembelajaran dapat ditingkatkan menggunakan media pembelajaran yang inovatif dan menyenangkan. Selama ini, pembelajaran eksperimen asam basa di SMA selalu identik dengan reagen kimia dan kurang meminimalisir limbah, sehingga perlu terobosan produk berupa media pembelajaran berbasis Green Labyrinth dari limbah sayur dan buah lokal yang sangat potensial dan eco-friendly. Penelitian ini bertujuan untuk menghasilkan, menganalisis kualitas, dan menyelidiki efektivitas penggunaan produk untuk SMA. Pengembangan produk mengacu pada model pengembangan 4-D yang dimodifikasi dengan menganalisis kebutuhan media pembelajaran asam basa di kelas XI SMA, merancang konsep dan penggunaan media, mengembangkan media, melakukan validasi dan penilaian dari ahli, guru kimia, dan peer reviewer, dan uji coba skala kecil dengan mahasiswa dan siswa SMA. Data kuantitatif dan kualitatif dianalisis dengan model Rasch dan deskriptif. Hasil penelitian menunjukkan bahwa produk yang dikembangkan telah memenuhi kriteria valid dengan rata-rata koefisien validitas 0,85, reliabel dengan nilai Crombach Alpha 0,78, respon sangat baik dari mahasiswa dan siswa SMA terhadap produk, efektif, dan praktis sebagai media pembelajaran dan permainan edukatif untuk SMA.
\end{abstract}

Kata kunci: media pembelajaran; asam basa; inovatif; green labyrinth

\begin{abstract}
Learning media is one of the essential parts in supporting the success of the teaching and learning process. The meaningfulness of learning can be improved using innovative and fun learning media. During this time, the learning of acid base experiments in senior high school has always been identical with chemical reagents and does not minimize waste, so it is necessary to breakthrough products in Green Labyrinth-based learning media from local vegetables and fruits waste that are very potential and eco friendly. This study aims to produce, analyze quality, and investigate the effectiveness of the use of products for senior high school. Product development refers to the modified 4-D development model by analyzing the needs of acid base learning media in grade 11 of high school, designing the concept and use of media, developing media, validating and evaluating from experts, chemistry teachers, and peer reviewers, and small trial groups with students and high school students. Quantitative and qualitative data were analyzed with Rasch model and descriptive. The results show that the product developed had fulfilled valid criteria with average validity coefficient of 0.85 , reliable with Cronbach Alpha value of 0.78 , very good response from students and high school students to the product, effective, and practical as learning media and educational games for senior high school.
\end{abstract}

Keywords: learning media; acid base; innovative; green labyrinth

\footnotetext{
${ }^{1}$ Corresponding author: Prodi Pendidikan Kimia, Universitas Sanata Dharma, Yogyakarta, Indonesia. Email: johnsenharta@usd.ac.id
} 


\section{PENDAHULUAN}

Memasuki Era Revolusi Industri 4.0, tidak dapat dipungkiri bahwa pendidikan dituntut maksimal untuk meningkatkan sumber daya manusia. Pendidikan di Era Revolusi Industri 4.0 memiliki ciri khas serba cepat dan update. Fenomena kekinian ditandai dengan hadirnya generasi milenial yang modern, yang tidak suka berlama-lama duduk di ruang kelas. Kegiatan belajar mengajar yang monoton di kelas sudah tidak cocok lagi karena sangat membosankan dan dapat menurunkan gairah belajar siswa (Wati \& Kamila, 2019). Oleh karena itu, guru ditantang untuk mampu berinovasi menciptakan pembelajaran yang aktif, inovatif, kreatif, efektif, menyenangkan, gembira dan berbobot.

Kimia merupakan salah satu bidang ilmu sains yang dianggap abstrak dan cukup sulit bagi kebanyakan siswa (Yumna, 2017). Kesulitan siswa dalam memahami konsep kimia sampai sekarang ini salah satunya dapat disebabkan karena sifatnya yang teoritis dan kurang menekankan aspek psikomotorik. Sementara itu, proses pembelajaran pada Kurikulum 2013 menuntut siswa untuk berperan aktif, mandiri, dan berpikir kritis, sehingga siswa harus memiliki kemampuan berpikir tingkat tinggi. Namun, tidak semua siswa memiliki kemampuan tersebut, sehingga kimia dianggap sebagai suatu ilmu yang sulit. Merespon hal ini, media pembelajaran menjadi hal yang sangat penting dan dapat dijadikan alternatif karena dapat membantu dalam implementasi materi kimia di SMA. Penggunaan media pembelajaran dapat mempermudah siswa dalam memahami sesuatu yang abstrak menjadi lebih konkret (Afidah, 2013) dan memperjelas penyajian pesan dan informasi sehingga dapat memperlancar dan meningkatkan proses dan hasil belajar (Sukiman, 2012).

Pencemaran akibat penggunaan berbagai reagen kimia yang dapat menyebabkan kerusakan lingkungan dan kesehatan bukanlah hal yang asing. Sebagai contoh, penggunaan indikator larutan untuk praktikum di SMA dapat menyebabkan pencemaran lingkungan. Oleh karena itu, berbagai usaha dilakukan untuk menemukan suatu pendekatan yang dapat mencegah pencemaran akibat bahan kimia. Kimia hijau atau green chemistry merupakan sebuah pendekatan yang sangat baik diterapkan, terlebih pada pembelajaran kimia di sekolah. Sanghi (2003) menyatakan bahwa green chemistry merupakan suatu gagasan untuk melindungi kesehatan dan lingkungan dengan cara meminimalisir limbah bahan kimia dengan menggantinya dengan bahan yang ramah lingkungan (bahan berasal dari alam).

Berdasarkan prinsip green chemistry tersebut, peneliti berinisiatif mengembangkan media pembelajaran dengan memanfaatkan bahan-bahan dari lingkungan sekitar yang ramah lingkungan demi meminimalisir banyaknya limbah dan melindungi lingkungan. Media pembelajaran berbasis Green Labyrinth yang dikembangkan dapat menunjang pembelajaran kimia asam basa di SMA.

Penelitian ini bertujuan untuk menghasilkan media pembelajaran berbasis Green Labyrinth yang valid, sehingga dapat diimplementasikan dalam materi asam basa di SMA, menghasilkan media pembelajaran berbasis Green Labyrinth yang efektif sehingga dapat diimplementasikan dalam materi asam basa di SMA, menghasilkan media pembelajaran berbasis Green Labyrinth yang praktis sehingga dapat diimplementasikan dalam materi asam basa di SMA, dan menghasilkan media pembelajaran berbasis Green Labyrinth yang aman sehingga dapat diimplementasikan dalam materi asam basa di SMA. 


\section{METODE}

Penelitian ini merupakan penelitian pengembangan yang mengacu pada model 4D (Thiagarajan, Semmel, \& Semmel, 1974: 5) yaitu Define, Design, Develop, dan Disseminate. Pada tahap Disseminate dilakukan modifikasi karena uji coba hanya dilakukan dalam skala kecil. Penelitian ini dilaksanakan selama bulan Mei hingga September 2019.

Sampel dipilih melalui teknik random sampling dengan melibatkan lima mahasiswa semester lima Prodi Pendidikan Kimia Universitas Sanata Dharma, lima siswa kelas XII SMA Negeri 6 Yogyakarta untuk uji coba skala kecil tahap awal, dan 30 siswa kelas XII SMA Negeri 6 Yogyakarta untuk uji coba skala kecil tahap kedua sebagai subjek penelitian.

Data kualitatif dan kuantitatif dalam penelitian ini diperoleh melalui instrumen lembar validasi terhadap pengembangan media pembelajaran asam basa berbasis green labyrinth, lembar wawancara, dan kuesioner respon terhadap produk yang dikembangkan. Data kualitatif dan kuantitatif yang diperoleh dianalisis secara deskriptif untuk menjelaskan pengembangan dan uji coba terbatas yang telah dilakukan, serta model Rasch untuk menganalisis reliabilitas kuesioner dari responden.

\section{HASIL DAN PEMBAHASAN}

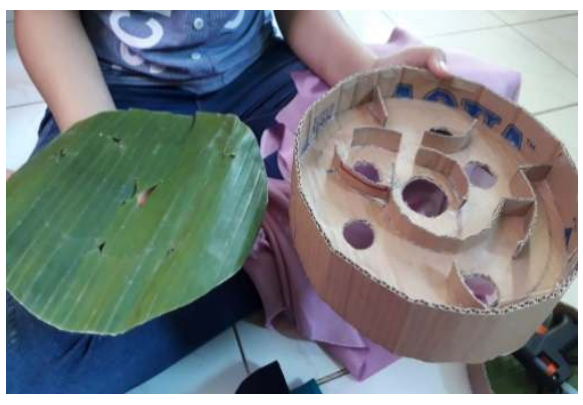

Gambar 1. Proses Pembuatan Media Pembelajaran Green Labyrinth

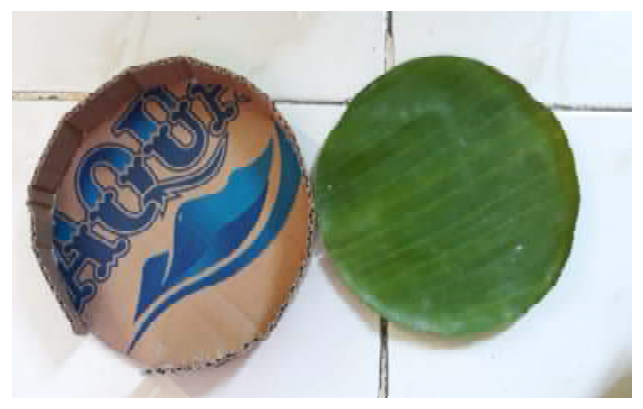

Gambar 2. Produk Perancangan Media

Pembelajaran

Berdasarkan Gambar 1 dan 2, pembuatan media pembelajaran Green Labyrinth memiliki bahan ecofriendly yang berasal dari lingkungan sekitar dan merupakan limbah atau bahan yang tidak terpakai yaitu kardus beragam ukuran, daun pisang, cup kecil, lem tembak, kain perca, cat air, dan gundu. Kardus yang beragam ukuran didesain, sehingga memiliki dua bentuk yaitu lingkaran dan persegi panjang. Daun pisang dibentuk lingkaran seukuran dengan lingkaran kardus. Pada kardus berbentuk lingkaran, bulatan-bulatan kecil dibentuk sesuai dengan konsep labirith yang diinginkan. Bulatan agak besar dibuat di tengah lingkaran kardus yang ukurannya disesuaikan dengan cup kecil sebagai wadah indikator alami. Gundu yang digunakan merupakan kelerang yang ditempelkan kapas. 


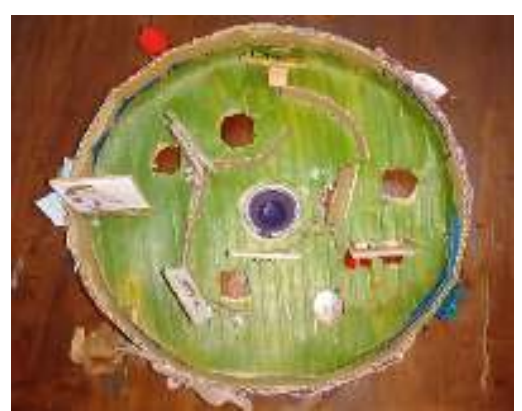

Gambar 3. Tampilan Atas Green Labyrinth

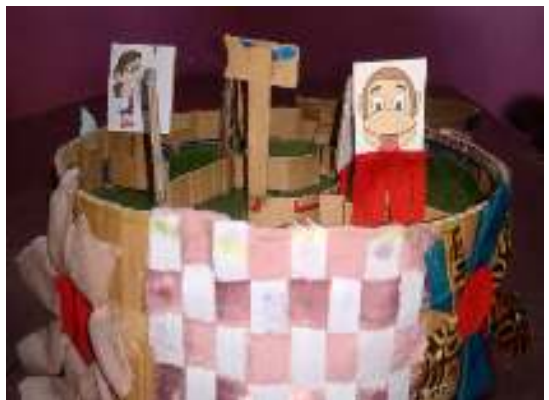

Gambar 4. Tampilan Samping Green Labyrinth

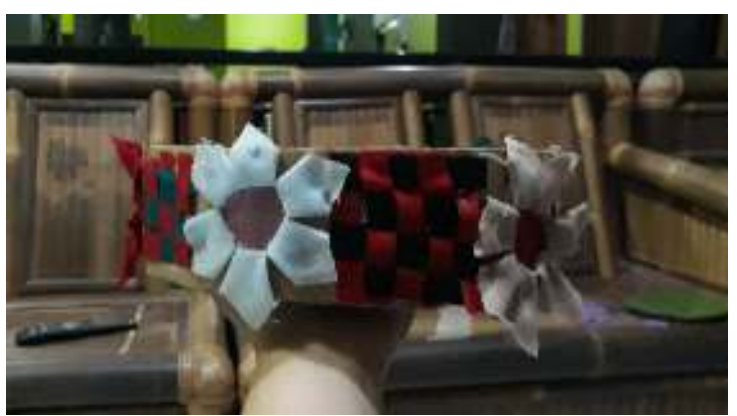

Gambar 5. Hiasan Kain Perca untuk Memperindah Green Labyrinth

Gambar 3, 4, dan 5 merupakan produk akhir media pembelajaran Green Labyrinth. Komponen yang terdapat dalam media pembelajaran meliputi mysterious bole, great bole, labirith, hiasan kain perca, dan karton penutup. Mysterious hole merupakan lubang-lubang yang terdapat pada lintasan labirin yang menyebabkan pemain keluar dari labirin sehingga setiap pemain harus mengulang dari awal jika masuk ke dalam lubang. Great bole merupakan lubang berisi indikator. Gundu yang ditempel kapas akan menyerap sampel larutan. Kain perca digunakan untuk menutupi bekas karton yang rusak dan dapat bertindak sebagai hiasan pada Green Labyrinth. 
Tabel 1. Hasil Validasi Berdasarkan Penilaian Validator dan Peer Reviewer

\begin{tabular}{|c|c|c|c|c|c|c|}
\hline $\begin{array}{l}\text { Validator } \\
\text { dan Peer } \\
\text { Reviewer }\end{array}$ & $\begin{array}{c}\text { Item } 1 \\
\text { Inovasi } \\
\text { Pengembangan } \\
\text { Produk }\end{array}$ & $\begin{array}{c}\text { Item } 2 \\
\text { Kreativitas } \\
\text { Pengembangan } \\
\text { Produk }\end{array}$ & $\begin{array}{c}\text { Item } 3 \\
\text { Penampilan } \\
\text { Produk }\end{array}$ & $\begin{array}{c}\text { Item } 4 \\
\text { Kelengkapan } \\
\text { dan } \\
\text { Kejelasan } \\
\text { Komponen } \\
\text { dalam } \\
\text { Produk } \\
\end{array}$ & $\begin{array}{c}\text { Item } 5 \\
\text { Kebermaknaan } \\
\text { Pembelajaran } \\
\text { Kimia Asam } \\
\text { Basa } \\
\text { menggunakan } \\
\text { Produk } \\
\end{array}$ & $\begin{array}{c}\text { Item } 6 \\
\text { Efektivitas } \\
\text { Penggunaan } \\
\text { Produk dalam } \\
\text { Pembelajaran } \\
\text { Kimia Asam Basa }\end{array}$ \\
\hline $\begin{array}{l}\text { Validator } \\
1\end{array}$ & 4 & 4 & 3 & 3 & 4 & 4 \\
\hline $\begin{array}{l}\text { Validator } \\
2\end{array}$ & 3 & 3 & 3 & 3 & 3 & 3 \\
\hline $\begin{array}{l}\text { Validator } \\
3\end{array}$ & 4 & 4 & 3 & 4 & 4 & 4 \\
\hline $\begin{array}{l}\text { Peer } \\
\text { Reviewer } \\
1\end{array}$ & 4 & 4 & 3 & 4 & 4 & 4 \\
\hline $\begin{array}{l}\text { Peer } \\
\text { Reviewer } \\
2\end{array}$ & 3 & 4 & 3 & 4 & 3 & 4 \\
\hline $\begin{array}{l}\text { Peer } \\
\text { Reviewer } \\
3\end{array}$ & 4 & 4 & 3 & 4 & 4 & 3 \\
\hline $\begin{array}{l}\text { Total } \\
\text { Skor }\end{array}$ & 22 & 23 & 18 & 22 & 22 & 22 \\
\hline
\end{tabular}

Berdasarkan Tabel 1, pada item 1 yaitu Inovasi Pengembangan media pembelajaran Green Labyrinth memiliki total skor 22, dimana rata-rata kriteria penilaian berada pada kategori sangat baik. Item 2 yaitu Kreativitas Pengembangan media pembelajaran Green Labyrinth tergolong baik dengan perolehan total skor 23, dimana semua penilaian yang diberikan validator berada pada kategori sangat baik. Item 3 merupakan penilaian terhadap Penampilan media pembelajaran Green Labyrinth memperoleh total skor 18 yang artinya produk termasuk kategori baik. Pada item 4 yaitu Kelengkapan dan Kejelasan Komponen dalam media pembelajaran Green Labyrinth masuk ke dalam kategori sangat baik dengan perolehan total skor 22. Dari segi Kebermaknaan Pembelajaran Kimia Asam Basa menggunakan media pembelajaran Green Labyrinth (item 5), produk tergolong kategori sangat baik dengan total skor 22. Pada penilaian item 6 yaitu Efektivitas penggunaan media pembelajaran Green Labyrinth dalam Pembelajaran Kimia Asam Basa, memperoleh total skor 22 dan termasuk dalam kategori sangat baik.

Selain dosen, validasi juga dilakukan oleh satu orang guru kimia di SMA Negeri 6 Yogyakarta. Penjelasan yang berkaitan dengan proses pembuatan, pemilihan alat dan bahan, serta cara penggunaan media pembelajaran dilakukan secara mendalam. Pada saat wawancara, guru menyatakan bahwa produk yang dikembangkan sangat kreatif dan ramah lingkungan. Pendidik juga mencoba memainkan produk Green Labyrinth. Pada saat guru menggunakan produk, pendidik juga terlihat antusias dan dapat diimplementasikan di SMA. Selain itu, guru kimia juga menyatakan bahwa akan menggunakan produk Green Labyrinth karena terinspirasi dari pengembangan produk yang dilakukan. 


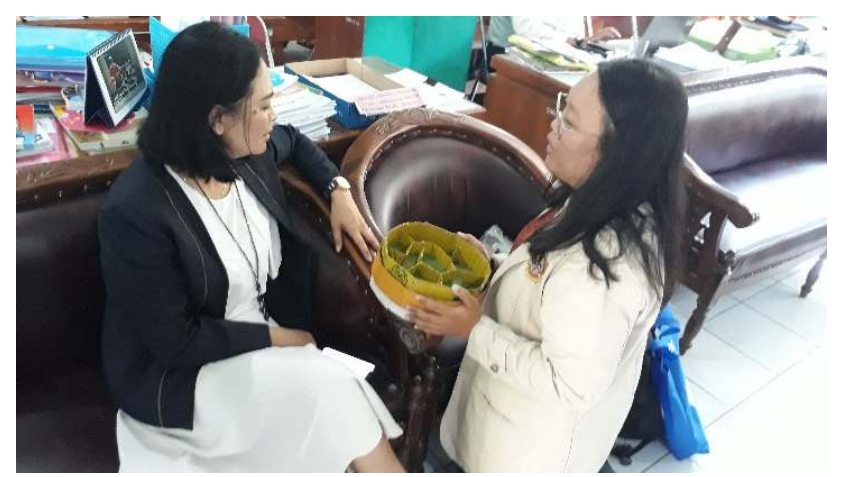

Gambar 6a. Penjelasan kepada Guru Kimia

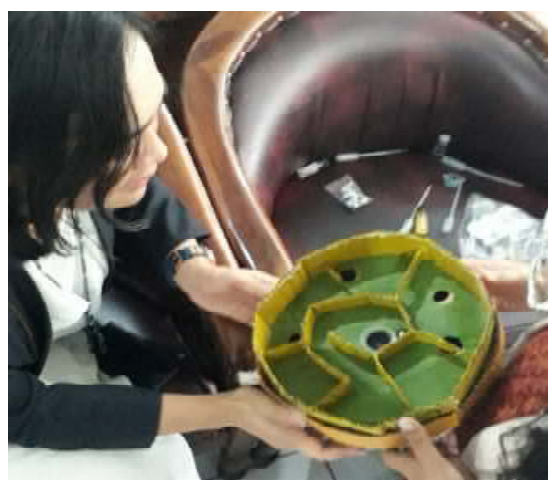

Gambar 6b. Guru Kimia Mencoba Produk Green Labyrinth

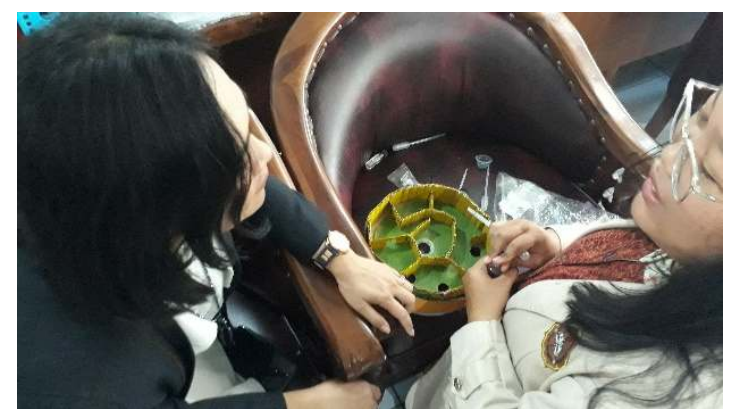

Gambar 6c. Wawancara dengan Guru Kimia

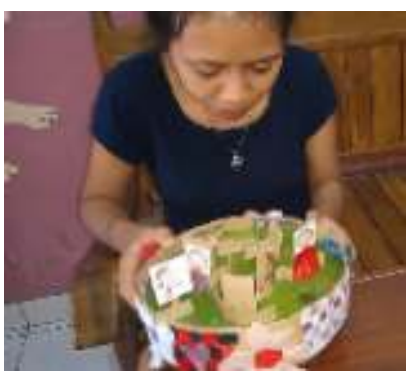

Gambar 7a. Uji Coba oleh mahasiswa 1

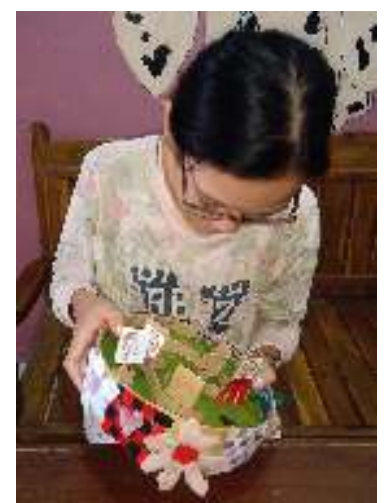

Gambar 7d. Uji Coba oleh mahasiswa 4

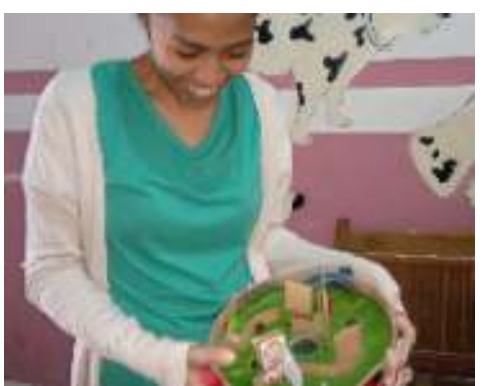

Gambar 7b. Uji Coba oleh mahasiswa 2

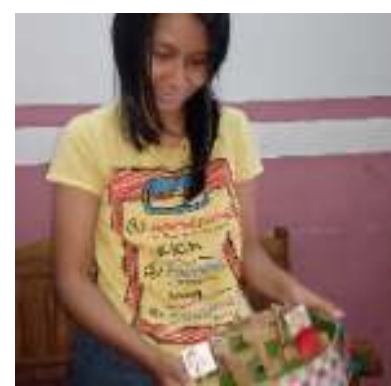

Gambar 7c. Uji Coba oleh mahasiswa 3

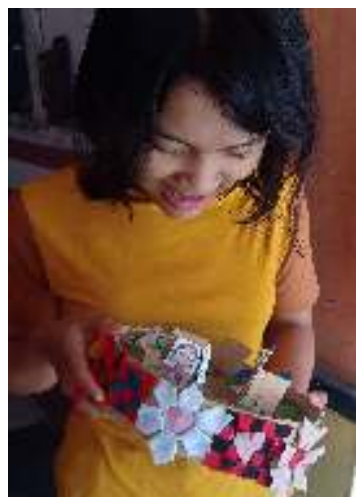

Gambar 7e. Uji Coba oleh mahasiswa 5 
Berdasarkan Gambar 7a hingga 7e, media pembelajaran Green Labyrinth telah diuji cobakan kepada lima mahasiswa semester lima Prodi Pendidikan Kimia, Universitas Sanata Dharma, secara bergantian. Hasil pengamatan menunjukkan bahwa semua mahasiswa sangat antusias dan senang memainkan media pembelajaran. Secara keseluruhan, mahasiswa ingin terus memainkan dan mencoba menggunakan media pembelajaran Green Labyrinth berulang kali.

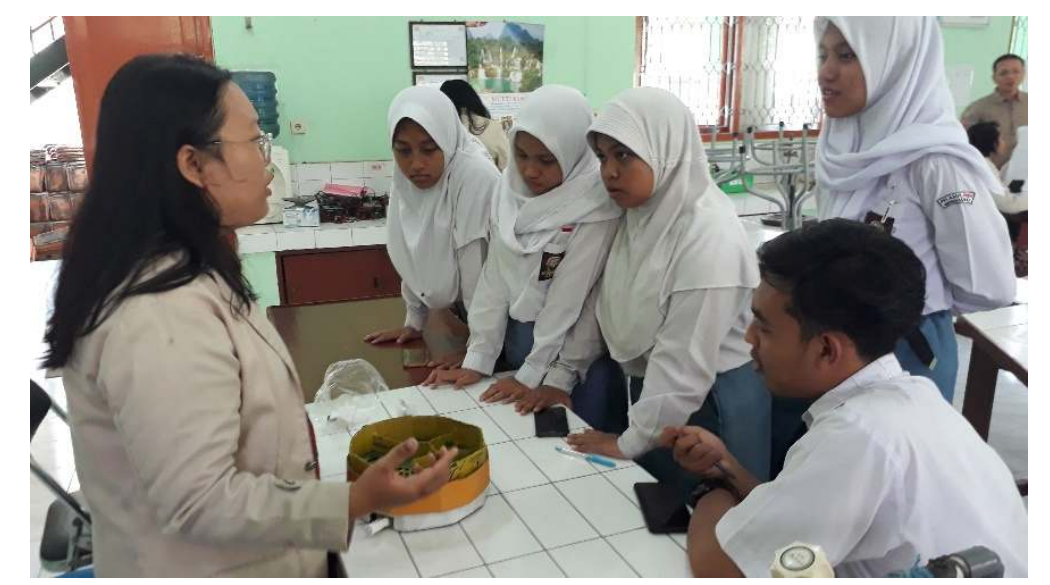

Gambar 8. Penjelasan Produk kepada Peserta Didik

Pengujian efektivitas dalam uji coba skala kecil tahap awal produk Green Labyrinth dilakukan pada lima orang peserta didik kelas XII di SMA Negeri 6 Yogyakarta. Uji coba skala kecil diawali dengan penjelasan produk secara mendalam baik terhadap proses pemilihan bahan, proses pembuatan produk, dan cara penggunaan terkait dengan sampel dan indikator asam basa dalam media pembelajaran kimia asam basa. Peserta didik merasa antusias dan tertarik dengan pengembangan produk Green Labyrinth yang dikembangkan.

Setelah diberi penjelasan terkait dengan produk, peserta didik pun memainkan produk sesuai dengan petunjuk penggunaan yang diberikan. Kelima peserta didik mencoba produk yang dikembangkan dengan antusias dan semangat. Semua peserta didik dapat mengamati perubahan warna pada larutan indikator alami. Perubahan warna yang terjadi pada kubis ungu disebabkan oleh larutan sampel yang bersifat asam dan basa. Peserta didik mampu menjelaskan perubahan warna yang terjadi akibat perbedaan sifat pada larutan sampel yang digunakan.

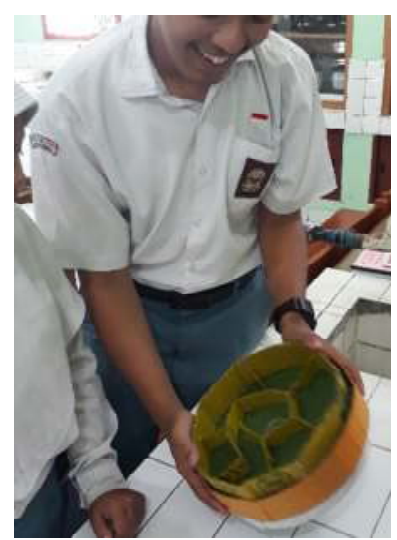

Gambar 9a. Peserta didik 1 memainkan Green Labyrinth

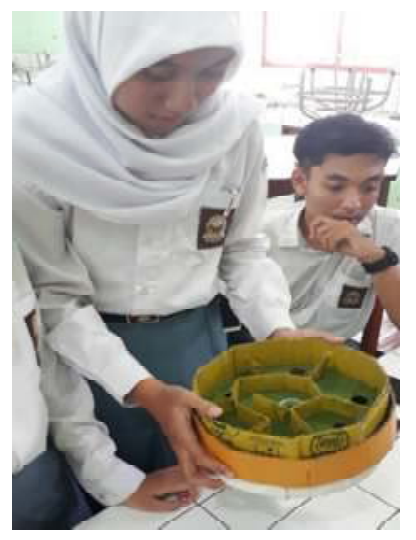

Gambar 9b. Peserta didik 2 memainkan Green Labyrinth 


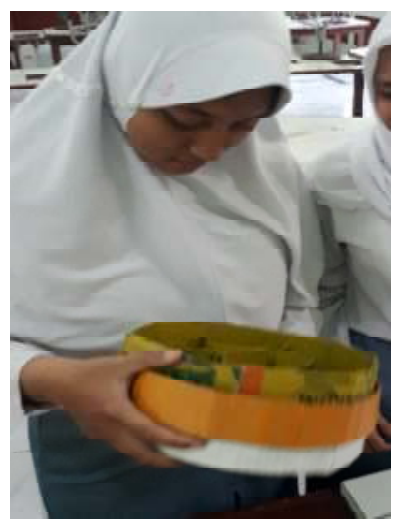

Gambar 9c. Peserta didik 3 memainkan Green Labyrinth

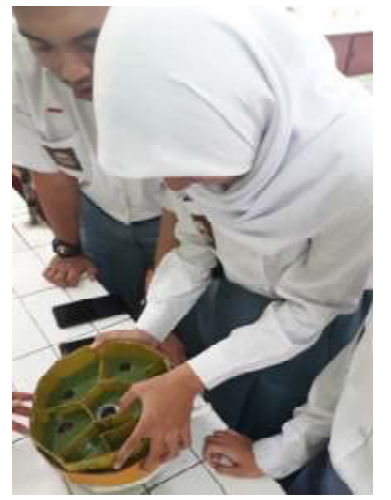

Gambar 9d. Peserta didik 4 memainkan Green Labyrinth

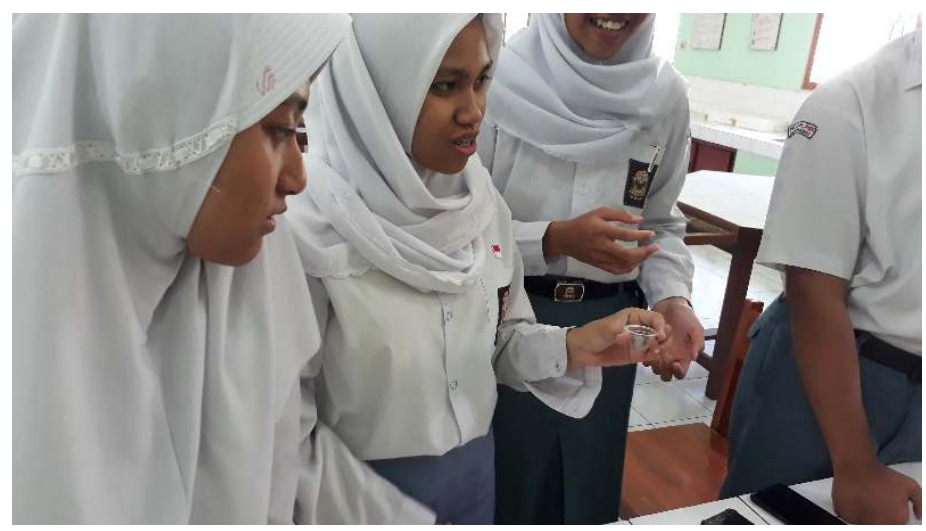

Gambar 9e. Tanya Jawab dengan Peserta Didik

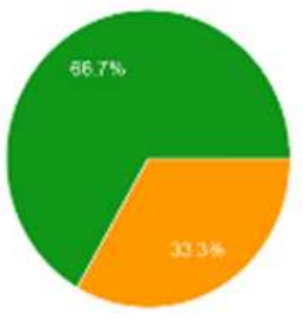

Gambar 10a. Tanggapan Mahasiswa tentang Inovasi Pengembangan Produk

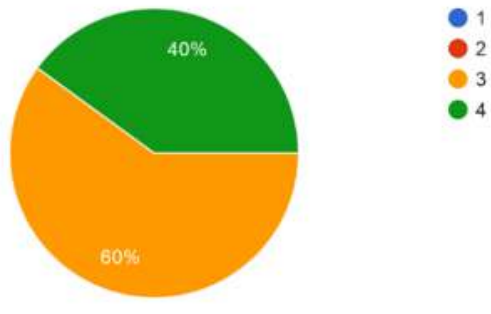

Gambar 10b. Tanggapan Peserta Didik tentang Inovasi Pengembangan Produk

Berdasarkan Gambar 10a, tanggapan mahasiswa terhadap pernyataan nomor 1, yaitu "Inovasi Pengembangan Produk berupa Media Pembelajaran Berbasis Green Labyrinth untuk Kimia Asam Basa di SMA", sebanyak 66,7\% mahasiswa menjawab sangat baik dan 33,3\% menjawab produk tergolong baik. Menurut Gambar 10b, sebanyak 40\% peserta didik menjawab sangat baik dan $60 \%$ peserta didik menjawab baik terkait inovasi. Tanggapan dari mahasiswa dan peserta didik ini menunjukkan bahwa produk tergolong inovatif untuk dikembangkan. 


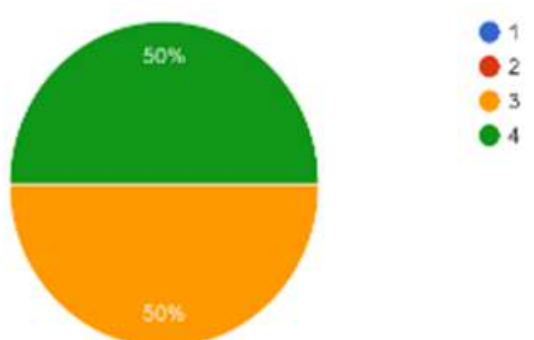

Gambar 11a. Tanggapan Mahasiswa tentang Kreativitas Pengembangan Produk

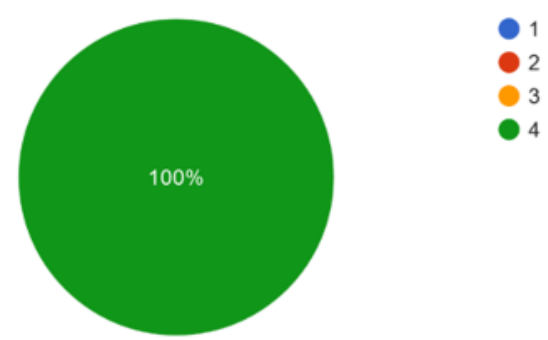

Gambar 11b. Tanggapan Peserta Didik tentang Kreativitas Pengembangan Produk

Berdasarkan Gambar 11a, tanggapan mahasiswa terhadap pernyataan nomor 2, yaitu "Kreativitas Pengembangan Produk berupa Media Pembelajaran Asam Basa Berbasis Green Labyrinth di SMA" memperlihatkan bahwa 50\% mahasiswa menjawab sangat baik dan 50\% menjawab baik. Gambar 11b menunjukkan bahwa 100\% peserta didik setuju bahwa produk tergolong sangat kreatif. Tanggapan dari mahasiswa dan peserta didik ini menunjukkan bahwa produk tergolong kreatif dan dapat terus dikembangkan.

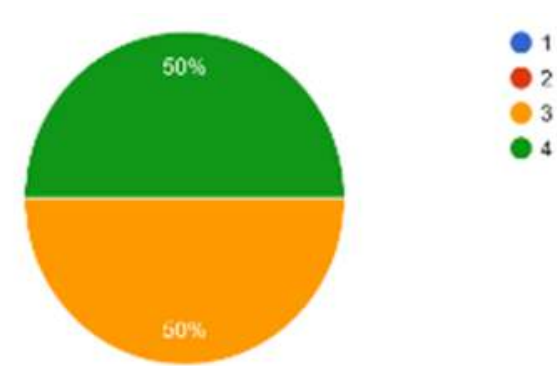

Gambar 12a. Tanggapan Mahasiswa tentang Kreativitas Pengembangan Produk

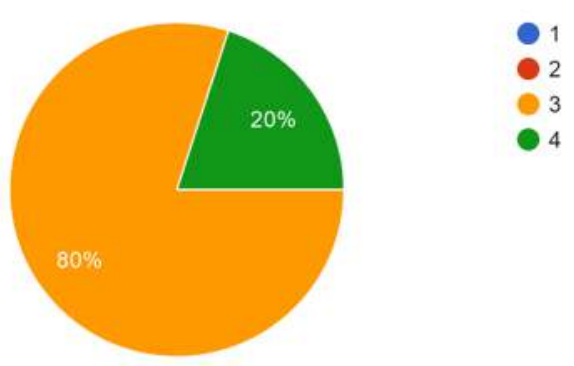

Gambar 12b. Tanggapan Peserta Didik tentang Kreativitas Pengembangan Produk

Berdasarkan Gambar 12a, tanggapan mahasiswa terhadap pernyataan nomor 3, yaitu "Penampilan Produk berupa Media Pembelajaran Kimia Asam Basa Berbasis Green Labyrinth" menunjukkan bahwa 50\% mahasiswa menjawab sangat baik dan 50\% menjawab baik. Gambar 12b menunjukkan bahwa 20\% peserta didik menjawab sangat baik dan $80 \%$ menjawab baik. Tanggapan dari mahasiswa dan peserta didik ini menunjukkan bahwa secara umum, penampilan produk dinilai baik.

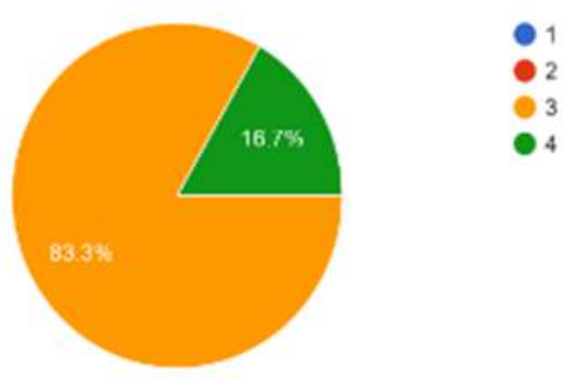

Gambar 13a. Tanggapan Mahasiswa tentang Kelengkapan dan Kejelasan Komponen dalam Produk

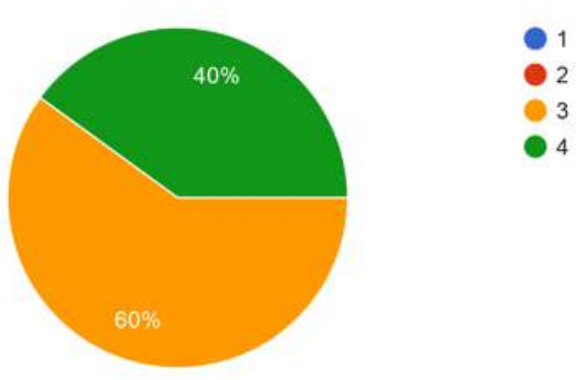

Gambar 13b. Tanggapan Peserta Didik tentang Kelengkapan dan Kejelasan Komponen dalam Produk 
Gambar 13a merupakan tanggapan mahasiswa dan peserta didik terhadap pernyataan nomor 4, yaitu "Kelengkapan dan Kejelasan Komponen dalam Produk berupa Media Pembelajaran Green Labyrinth terhadap Pembelajaran Asam Basa di SMA" memperlihatkan bahwa 16,7\% mahasiswa menjawab sangat baik dan 83,3\% menjawab baik. Sementara itu, Gambar 13b memperlihatkan $40 \%$ peserta didik menjawab sangat baik dan 60\% menjawab baik. Tanggapan tersebut menunjukkan bahwa mahasiswa dan peserta didik dapat memahami semua komponen dan kejelasan dalam menggunakan produk.

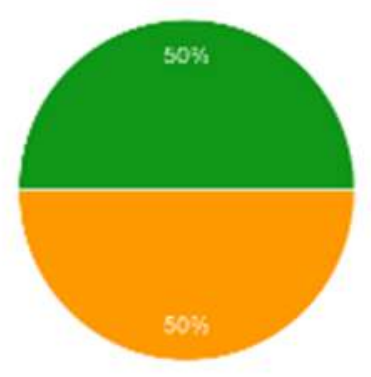

Gambar 14a. Tanggapan Mahasiswa tentang Kebermaknaan Pembelajaran Kimia Asam Basa menggunakan Produk

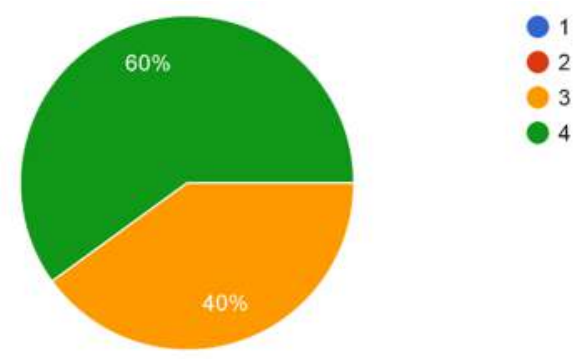

Gambar 14b. Tanggapan Peserta Didik tentang Kebermaknaan Pembelajaran Kimia Asam Basa menggunakan Produk

Berdasarkan Gambar 14a yang merupakan tanggapan mahasiswa terhadap pernyataan nomor 5, yaitu "Kebermaknaan Pembelajaran Kimia Asam Basa menggunakan Produk berupa Media Pembelajaran berbasis Green Labyrinth", sebanyak 50\% mahasiswa menjawab sangat baik dan 50\% menjawab baik. Sementara itu, Gambar 14b menunjukkan bahwa 60\% peserta didik menjawab sangat baik dan 40\% menjawab baik. Mahasiswa dan peserta didik menyatakan bahwa belajar kimia asam basa, khususnya sifat larutan dan indikator asam basa dapat bermakna melalui permainan produk yang edukatif.

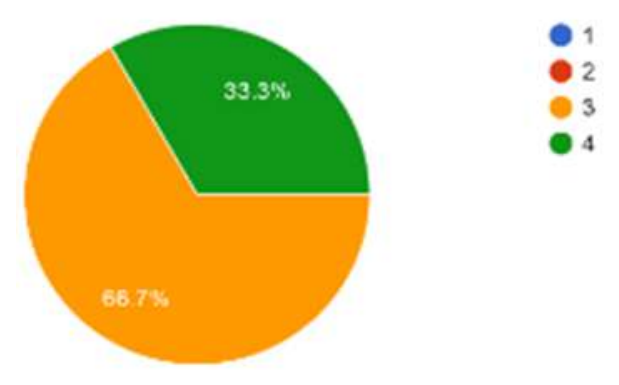

Gambar 15a. Tanggapan Mahasiswa tentang Efektivitas Penggunaan Produk dalam Pembelajaran Kimia Asam Basa

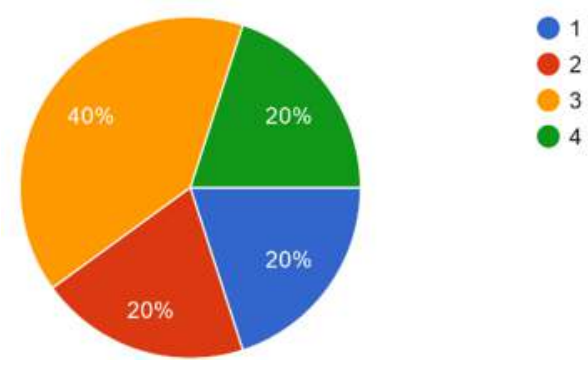

Gambar 15b. Tanggapan Peserta Didik tentang Efektivitas Penggunaan Produk dalam Pembelajaran Kimia Asam Basa

Berdasarkan Gambar 15a, tanggapan mahasiswa dan peserta didik terhadap pernyataan nomor 6, yaitu "Efektivitas Penggunaan Produk berupa Media Pembelajaran Green Labyrinth dalam Pembelajaran Kimia Asam Basa" menunjukkan bahwa sebanyak 66,7\% mahasiswa menjawab sangat baik dan 33,3\% menjawab baik. Sementara itu pada Gambar 15b, terlihat bahwa 20\% peserta didik menjawab sangat baik, $40 \%$ menjawab baik, $20 \%$ menjawab kurang baik dan 20\% 
peserta didik menjawab tidak baik. Berdasarkan tanggapan mahasiswa menunjukkan bahwa produk efektif untuk dilanjutkan dalam implementasi pembelajaran kimia asam basa di SMA. Namun, tanggapan dari peserta didik menyatakan produk cukup efektif untuk dilanjutkan dalam implementasi pembelajaran kimia asam basa di SMA.

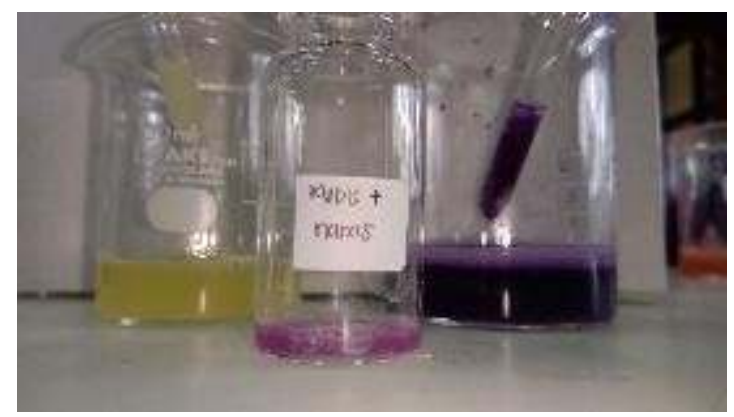

Gambar 16a. Perubahan Warna Indikator Kubis Ungu pada Sampel Asam (merah)

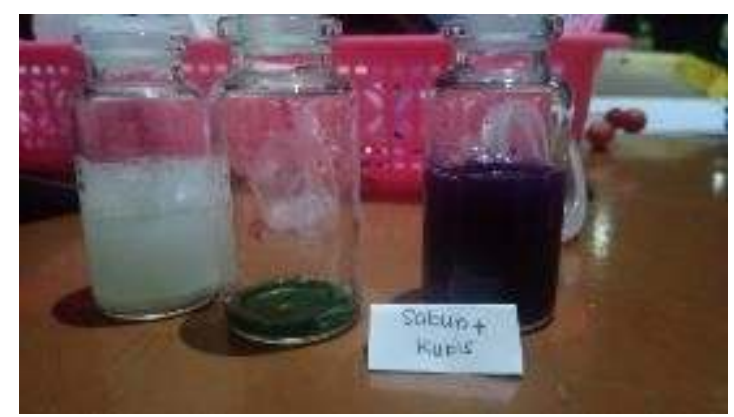

Gambar 16b. Perubahan Warna Indikator Kubis Ungu pada Sampel Basa (hijau)

Tahap Define dilakukan dengan menemukan literatur dari artikel jurnal terkait media pendukung untuk pembelajaran asam basa yang berbasis kimia hijau. Media pembelajaran merupakan perangkat pembelajaran yang memiliki fungsi untuk memperjelas pesan yang disampaikan pendidik atau disebut juga sebagai alat bantu mengajar (Sudjana \& Rivai, 2011). Media memudahkan siswa belajar, memberikan pengalaman konkrit, menarik perhatian, mengaktifkan indera peserta didik, dan membangkitkan dunia teori dengan realitanya (Primasari, dkk., 2014). Listyarini et al (2019) menekankan bahwa pengembangan media pembelajaran kimia dalam konteks praktikum skala kecil terintegrasi kimia hijau dapat meningkatkan kesadaran akan pentingnya masalah lingkungan akibat penggunaan reagen kimia secara berlebihan. Untuk itu, media yang dikembangkan tentunya harus dibuat menarik dan mengedukasi guru kimia dan peserta didik.

Penggunaan semua bahan dalam produk ini mengacu pada prinsip kimia hijau, beberapa di antaranya:

1. Mencegah timbulnya limbah. Hal ini terlihat dari penggunaan indikator dan sampel dalam jumlah sedikit sehingga limbah yang dihasilkan tidak berbahaya bagi lingkungan.

2. Menggunakan pelarut yang aman. Hal ini terlihat dari penggunaan pelarut yang berasal dari ekstrak buah dan sayuran sehingga limbah yang dihasilkan tidak mencemari lingkungan sekitar.

3. Meminimalisir potensi kecelakaan. Penggunaan bahan dan pelarut yang berasal dari lingkungan baik barang bekas maupun ekstrak buah dan sayur aman untuk digunakan.

Green Labyrinth merupakan salah satu media/ alat peraga yang dapat menentukan sifat asam basa suatu larutan, indikator yang digunakan, dan trayek $\mathrm{pH}$ dari larutan yang diuji. Alat peraga ini dapat dijadikan sebagai praktikum inovatif dengan menggunakan bahan-bahan yang berasal dari lingkungan sekitar seperti 
limbah atau barang-barang tidak terpakai. Salah satu keuntungan menggunakan alat peraga ini adalah limbah yang dihasilkan sangat kecil dan ramah bagi lingkungan.

Green Labyrinth dapat menjadi salah satu cara bagi pendidik untuk meningkatkan kecintaan peserta didik terhadap kimia. Hal ini didukung dengan konsep Green Labyrinth sebagai praktikum penentuan sifat asam dan basa pada larutan yang dilakukan secara inovatif dan menarik. Pada praktikum penentuan sifat asam dan basa pada larutan, biasanya indikator yang sering digunakan adalah kertas lakmus, indikator universal maupun $\mathrm{pH}$ meter.

Pada Green Labyrinth, indikator yang digunakan merupakan indikator alami dari sayuran yang dapat menentukan sifat asam dan basa suatu larutan. Penggunaan indikator alami pada Green Labyrinth disesuaikan dengan prinsip kimia hijau dimana bahan dasar yang digunakan ramah bagi lingkungan (Sharma, dkk., 2008). Inovasi menggunakan indikator alami akan dipadukan dengan permainan interaktif dalam praktikum penentuan sifat asam dan basa pada larutan. Pembuatan alat peraga ini bertujuan untuk membantu pendidik meningkatkan kecintaan peserta didik terhadap kimia dan meningkatkan kreatifitas peserta didik serta pendidik untuk membuat praktikum yang ramah lingkungan serta sesuai dengan prinsip kimia hijau.

Green Labyrinth merupakan suatu media/ alat peraga inovatif yang dapat membantu pendidik dalam melaksanakan praktikum kimia dalam materi asam dan basa. Green Labyrinth menggunakan konsep bermain sambil belajar untuk menentukan sifat asam dan basa suatu larutan menggunakan indikator alami dari sayur-sayuran dan sampel yang digunakan berupa ekstrak buah dan sayur yang aman bagi lingkungan. Pada dasarnya alat peraga ini diciptakan untuk menumbuhkan kecintaan terhadap kimia serta sikap kritis peserta didik pada saat pelaksanaan praktikum kimia. Acuan terbentuknya Green Labyrinth berdasar pada materi kimia kelas XI yang berkaitan dengan konsep asam basa pada Kompetensi Inti (KI) 3 dan 4 yang diturunkan menjadi Kompetensi Dasar (KD) 3.10 dan 4.10.

Tabel 2. KI dan KD untuk Topik Asam dan Basa

\begin{tabular}{|c|c|}
\hline Kompetensi Inti (KI) & Kompetensi Dasar (KD) \\
\hline $\begin{array}{l}\text { 3: Memahami, menerapkan, dan menganalisis } \\
\text { pengetahuan faktual, konseptual, prosedural, dan } \\
\text { metakognitif berdasarkan rasa ingin tahunya tentang } \\
\text { ilmu pengetahuan, teknologi, seni, budaya, dan } \\
\text { humanior dengan wawasan kemanusiaan, } \\
\text { kebangsaan, kenegaraan, } \\
\text { dan peradaban terkait penyebab fenomena dan } \\
\text { kejadian, seta menerapkan pengetahuan prosedural } \\
\text { pada bidang kajian yang spesifik sesuai dengan bakat } \\
\text { dan minatnya untuk memecahkan masalah }\end{array}$ & $\begin{array}{l}\text { 3.10 Menganalisis sifat larutan berdasarkan konsep } \\
\text { asam basa dan/ atau pH larutan }\end{array}$ \\
\hline $\begin{array}{l}\text { 4: Mengolah, menalar, dan menyaji dalam ranah } \\
\text { konkret dan ranah abstrak terkait } \\
\text { pengembangan dari yang dipelajarinya di sekolah } \\
\text { secara mandiri, bertindak secara efektif dan kreatif, } \\
\text { serta mampu menggunakan metoda sesuai kaidah } \\
\text { keilmuan }\end{array}$ & $\begin{array}{l}\text { 4.10 Mengajukan ide/gagasan tentang penggunaan } \\
\text { indikator yang tepat untuk menentukan keasaman } \\
\text { asam/basa atau titrasi asam/basa }\end{array}$ \\
\hline
\end{tabular}

Sesuai dengan tuntutan pada Kurikulum 2013 untuk topik ini, guru kimia harus kreatif dan inovatif dalam mengembangkan media pembelajaran yang menarik minta siswa untuk belajar kimia. Penemuan berbagai macam zat di lingkungan sekitar kita, terutama berbasis kearifan lokal dapat mengembangkan kemampuan berpikir kritis dan literasi peserta didik (Harta, 2019: 120), sehingga desain ini wajib dicoba dalam eksperimen kelas XI SMA.

Pada tahap Design, mulai dirancang media pembelajaran konvensional berbasis kimia hijau yang diberi nama green labyrinth untuk materi asam dan basa kelas XI SMA. Nama ini diberikan karena 
bahan dasar pembuatannya memanfaatkan material sederhana yang ecofriendly seperti daun pisang, kertas karton, buah-buahan dan sayuran lokal sebagai sampel dan atau indikator seperti jambu biji merah, nanas, tomat, dan kubis ungu, serta cup plastik kecil yang tidak terpakai lagi, namun bisa digunakan secara berulang dalam media pembelajaran ini. Labyrinth dirancang agar media pembelajaran ini dikemas dalam bentuk permainan yang menyenangkan, dan sampel akan berubah warna sesuai dengan indikator alami yang digunakan.

Setelah kerangka pembuatan media pembelajaran telah disusun dan dirancang, media pembelajaran green labyrinth asam basa ini mulai dikembangkan dengan tahapan sebagai berikut:

1. Desain labirin dibuat sesuai dengan yang diinginkan.

2. Lingkaran A dengan diameter $22 \mathrm{~cm}$ dibuat dari kardus/karton sebanyak 1 buah sebagai wadah bagian atas labirin.

3. Lingkaran $\mathrm{B}$ dengan diameter $18 \mathrm{~cm}$ dibuat dari kardus/karton sebanyak 1 buah sebagai wadah bagian bawah labirin.

4. Kardus/karton berukuran $40 \times 4 \mathrm{~cm}$ disiapkan sebanyak 2 buah, $40 \times 3 \mathrm{~cm}$ disiapkan sebanyak 2 buah.

5. Lingkaran A dibuat sesuai dengan desain yang telah disiapkan sebelumnya seperti sekat-sekat labirin, garis start dan finish, dan lain- lain.

6. Kardus/karton yang telah dipotong direkatkan dengan lem untuk menyatukan lingkaran A dan B.

7. Satu lapis daun pisang dibentuk dan dipotong dengan ukuran sama dengan lingkaran A.

8. Daun pisang yang telah dipotong diletakkan di atas lingkaran A sebagai pelapis.

9. Setelah itu, labirin yang telah terbentuk dibuat menarik dengan cara menghias sesuai dengan keinginan, misalnya menggunakan kain perca sebagai hiasan.

Pada tahap Develop, dilakukan validasi produk oleh dua dosen Prodi Pendidikan Kimia, Universitas Sanata Dharma dan satu orang guru kimia di SMA Negeri 6 Yogyakarta. Secara umum, ketiga validator setuju bahwa media pembelajaran asam basa berbasis green labyrinth telah memenuhi kriteria valid, sangat inovatif, kreatif, dan bisa dikembangkan lebih baik lagi.

Terlebih lagi respon guru kimia yang menyatakan bahwa pemanfaatan limbah di lingkungan sekitar untuk mengembangkan produk sangatlah baik dan menjadikan produk ini praktis, efektif, dan menyenangkan untuk siswa. Hal yang sama juga diungkapkan ketiga peer reviewer bahwa produk yang dikembangkan baik dan bisa diimplementasikan lebih lanjut di SMA. Secara umum, penilaian keenam rater ini telah memenuhi kriteria valid dengan rata-rata koefisien validitas 0,85 .

Tahap terakhir yaitu Disseminate dilakukan melalui uji coba skala kecil terhadap lima mahasiswa Prodi Pendidikan Kimia Universitas Sanata Dharma yang sangat merespon baik akan keberadaan produk ini. Mahasiswa setuju karena calon guru kimia perlu kreatif dalam memikirkan dan mengembangkan produk dapat digunakan untuk menunjang pembelajaran. Mahasiswa menyadari bahwa penggunaan media pembelajaran menjadi bagian penting dalam perancangan dan penyusunan Rencana Pelaksanaan Pembelajaran (RPP) yang memuat kegiatan pendidik dan peserta didik untuk mencapai kompetensi yang telah ditetapkan. RPP minimal memuat lima komponen yaitu tujuan pembelajaran, materi ajar, metode pembelajaran, sumber belajar (media pembelajaran), dan penilaian hasil belajar (Munadi, 2012).

Setelah mahasiswa, penelitian dilanjutkan dengan uji coba skala kecil di SMA Negeri 6 Yogyakarta. Uji coba tahap awal ini dilakukan terhadap lima peserta didik kelas XII SMA Negeri 6 Yogyakarta. Setelah uji keterbacaan tahap awal dilakukan, 30 peserta didik kelas XII di SMA ini juga dilibatkan dalam penggunaan produk green labyrinth ini. Peserta didik dibagi ke dalam enam kelompok dan mencoba memaknai pembelajaran asam basa melalui permainan edukatif. Peserta didik merasa senang dan antusias mengikutinya. Peserta didik dapat menganalisis bahwa indikator merupakan zat yang dapat mengalami perubahan warna pada kondisi yang berbeda. Indikator asam basa merupakan senyawa organik yang dapat berubah warna sesuai dengan pH-nya dan 
biasanya digunakan untuk membedakan larutan yang bersifat asam atau basa (Fessenden \& Fessenden, 1999). Dalam uji coba kali ini, digunakan kubis ungu sebagai indikator alami yang mengandung antosianin. Antosianin adalah pembentuk dasar pigmen warna ungu pada tanaman (Harborne, 1957). Kubis ungu merupakan sejenis tanaman sayuran yang mempunyai warna khas yaitu ungu. Kubis ungi mengandung beberapa zat yaitu air, protein, lemak, karbohidrat, serat, kalsium, fosfor, besi, natrium, kalium, beberapa vitamin, sianohidroksibutena, dan antosianin (Padmaningrum \& Salirawati 2007).

Berdasarkan pengujian warna indikator yang dilakukan dalam uji coba skala kecil, diperoleh informasi dari mahasiswa dan siswa bahwa sampel dari nanas, tomat, dan jambu biji merah menghasilkan warna merah, sedangkan sampel soda kue mengubah warna indikator kubis ungu menjadi hijau. Jika ditinjau dari perubahan warna seiring dengan perubahan $\mathrm{pH}$, warna ekstrak kubis ungu adalah merah pada $\mathrm{pH}$ 1, warna biru kemerahan pada $\mathrm{pH} 4$, warna ungu pada $\mathrm{pH} 6$, warna biru pada $\mathrm{pH} 8$, warna hijau pada $\mathrm{pH} 12$ dan warna kuning pada $\mathrm{pH}$ 13. Perubahan warna ini sesuai dengan perubahan warna pada antosianin untuk setiap perubahan $\mathrm{pH}$ (Harborne, 1957). Hal tersebut didukung dengan nilai $\mathrm{pH}$ yang dimiliki pepaya $\mathrm{pada} \mathrm{pH} 6,1$ dan nenas pada pH 4,7 (Angelia, 2017).

Di akhir pembelajaran, peserta didik diminta mengisi kuesioner mengenai respon terhadap produk melalui link google form. Hasil akhir kuesioner responden ini dianalisis dengan model Rasch dan menunjukkan nilai Alpha Cronbach sebesar 0,78 yang berarti bahwa reliabilitas tergolong baik dan konsisten. Peserta didik responsif terhadap pengembangan produk ini.

\section{KESIMPULAN}

Berdasarkan penelitian pengembangan yang telah dilakukan, dapat disimpulkan bahwa:

1. Produk berupa media pembelajaran berbasis Green Labyrinth yang valid, sehingga dapat diimplementasikan dalam materi asam basa di SMA. Hal ini ditunjukkan dengan hasil validasi yang menyatakan bahwa produk tergolong inovatif, kreatif, menarik, lengkap, jelas, bermakna, dan efektif.

2. Produk berupa media pembelajaran berbasis Green Labyrinth yang efektif, sehingga dapat diimplementasikan dalam materi asam basa di SMA. Hal ini ditunjukkan dari hasil observasi dan uji coba skala kecil yang mengindikasikan bahwa produk berupa media pembelajaran berbasis Green Labyrinth efektif digunakan untuk pembelajaran asam basa di SMA.

3. Produk berupa media pembelajaran berbasis Green Labyrinth yang praktis, sehingga dapat diimplementasikan dalam materi asam basa di SMA. Hal ini ditunjukkan dari hasil observasi dan uji coba skala kecil di mana responden dapat memahami dengan baik penggunaan produk berupa media pembelajaran berbasis Green Labyrinth.

4. Produk berupa media pembelajaran berbasis Green Labyrinth yang aman, sehingga dapat diimplementasikan dalam materi asam basa di SMA. Hal ini ditunjukkan dari observasi dan uji coba skala kecil dimana media, indikator dan sampel tidak menghasilkan limbah yang berbahaya bagi lingkungan dan kesehatan mahasiswa dan siswa.

\section{DAFTAR RUJUKAN}

Afidah, V. N. (2013). Pengembangan Media Pembelajaran Interaktif untuk Membangun Pemahaman Konsep Garis Singgung Persekutuan Dua Lingkaran. Jurnal Pendidikan Sains. 1 (3): 258 - 264.

Angelia, I.O. (2017). Kandungan pH, Total Asam Tertitrasi Padatan Terlarut dan Vitamin C Pada Beberapa Komoditas Hortikultura. Journal of Agritech Science. 1 (1): 68 - 74.

Fessenden, R.J., \& Fessenden, J.S. (1999). Kimia Organik Jilid 2. Jakarta: Erlangga.

Harborne, J.B. (1957). Spektral Methods of Characterizing Antocyanins. Journal Biochem. 7 (1): 22 - 28. 
Harta, J. (2019). Kajian Kurikulum Kimia SMA dan SMK. Yogyakarta: Deepublish.

Listyarini, R.V.; Pamenang, F.D.N.; Harta, J.; Wijayanti, L.W.; Asy'ari, M.; \& Lee, W. (2019). The Integration of Green Chemistry Principles into Small Scale Chemistry Practicum for Senior High School Students. Jurnal Pendidikan IPA Indonesia. 8 (3): 371-378.

Munadi Y. (2012). Media Pembelajaran. Jakarta: Gaung Persada Press.

Padmaningrum, R. T., \& Salirawati, D. (2007). Pengembangan Prosedur Penentuan Kadar CH3COOH secara Titrasi Asam Basa dengan Berbagai Indikator Alami. Laporan Penelitian. FMIPA. UNY.

Primasari, R., Zulfiani, \& Herlanti, Y. (2014). Penggunaan Media Pembelajaran di Madrasah Aliah Negeri Se-Jakarta Selatan. Jurnal Edusains. 6 (1): 68 - 72.

Sanghi, R. (2003). The Need For Green Chemistry: Environt Friendly Alternative. New Delhi: Naroso Publishing House.

Sharma, S.K., Chaudhary, A., \& Singh, R.V. (2008). Gray Chemistry Versus Green Chemistry: Challenges and Opportunities. Rasayan Journal Chemistry. 1 (1): 68-92 .

Sudjana, N \& Rivai, A. (2011). Media Pengajaran. Bandung: Sinar Baru Algesindo.

Sukiman. (2012). Pengembangan Media Pembelajaran. Yogyakarta: Pustaka Insan.

Wati, I \& Kamila, I. (2019). Pentingnya Guru Professional dalam Mendidik Siswa Milenial untuk Menghadapi Revolusi 4.0. Prosiding Seminar Nasional Pendidikan Program Pascasarjana Universitas PGRI Palembang. 364-370.

Thiagarajan, S., Semmel, D., \& Semmel, M. (1974). Instructional Development for Training Teachers of Exceptional Children. Minneapolis, Minnesota: Leadership Training Institute / Special Education, University of Minnesota.

Yumna, Y., Cawang \& Hadiarti, D. (2017). Pengaruh Model Pembelajaran Kooperatif Tipe TAI (Team Asissted Individualization) Berbantuan Video terhadap Hasil Belajar Siswa pada Sub Materi Konfigurasi Elektron Kelas X SMA Negeri 5 Pontianak. Ar-Razi Jurnal Ilmiah. 7 (1). 